2020-07-30

\title{
Explaining Italian foreign policy
}

\section{adjustment after Brexit: a Neoclassical realist account}

\section{Cladi, Lorenzo}

http://hdl.handle.net/10026.1/15708

\subsection{0/07036337.2020.1800676}

Journal of European Integration

Taylor \& Francis (Routledge)

All content in PEARL is protected by copyright law. Author manuscripts are made available in accordance with publisher policies. Please cite only the published version using the details provided on the item record or document. In the absence of an open licence (e.g. Creative Commons), permissions for further reuse of content should be sought from the publisher or author. 


\title{
EXPLAINING ITALIAN FOREIGN POLICY ADJUSTMENT AFTER \\ BREXIT: A NEOCLASSICAL REALIST ACCOUNT \\ Lorenzo Cladi and Andrea Locatelli
}

This is the accepted version of an article which is going to appear in the Journal of European Integration

\begin{abstract}
Drawing on a neoclassical realist approach, this article delves into the impact that Brexit is likely to have on Italian foreign policy. We argue that there are two areas of issue, which are particularly affected by Brexit. Firstly, the Italian relationship with France and Germany. Secondly, Italian defence policy within the European context. Although Italy has not appeared to have significantly changed its foreign policy course after the British referendum, policymakers in Rome have been concerned by the risks that Brexit entails for the country, and have reacted accordingly. We will observe the variation in governmental interest of three ruling coalitions which have alternated in power since 2016 and, through a neoclassical realist approach, we argue that the Italian response to Brexit has been shaped by both the international pressure to preserve its standing in Europe and the need shared by all governments to keep up to their electoral promises.
\end{abstract}




\section{EXPLAINING ITALIAN FOREIGN POLICY ADJUSTMENT AFTER \\ BREXIT: A NEOCLASSICAL REALIST ACCOUNT}

\section{Introduction}

When the British people voted, on $23^{\text {rd }}$ June 2016, to decide whether to remain in the European Union (EU) or not, the future of the European integration process was in doubt. At the time of writing, the long term consequences of Brexit are far from clear. Nevertheless, the literature has considerably expanded to include analysis of the EU's initiatives in the security realm (see among others Nissen 2017; Duke 2019). Quite surprisingly, what is missing so far is a systematic consideration of the strategic adjustment of EU member states following Brexit. The aim of this paper is therefore to shed light on a single case study of foreign policy adaptation after Brexit, i.e. Italy, which qualifies as a significant case study for several reasons.

For instance, Italy remains a major player in the EU arena although it has often been seen as a middle power punching above its weight in terms of foreign policy (see for instance Giacomello and Verbeek 2011; Walston 2011 and Brighi 2011; Carati and Locatelli 2015 among others). Moreover, Italy has so far owed some its influence to British support. It then follows that Brexit has a direct impact on the Italian standing within the EU. Furthermore, Italy and the UK have strong economic ties that Brexit may endanger: the UK is the world's fourth major target of Italian export, and the trade surplus amounts to about 11 billion Euros. On top of that, it is worth recalling that most of the commodities that Italy exports to the UK, such as food and mechanical engineering, could be hit by tariffs as high as $10 \%$ - meaning a potentially relevant trade disruption (Alber 2019).

Thirdly, and in difference to other EU countries, Italy has experienced three governmental changes since the Brexit referendum. In December 2016 Matteo Renzi resigned as Prime Minister (Kirchgaessner 2016) and was replaced by Paolo Gentiloni, who is a fellow member of the Democratic Party. Gentiloni's cabinet lasted for a mere 18 months. Following the March 2018 elections in which the governing centre-left coalition suffered a major defeat, the two populist, Euro-sceptic and anti-migrant parties - Matteo Salvini's The League and Luigi Di Maio's Five-Star Movement - found an uneasy compromise in a coalition government led by 
Giuseppe Conte. The Conte government was just as short-lived and the so-called yellow-green coalition broke up in August 2019. However, Conte formed a new government based on a coalition between the Five-Star movement and the centre-left Democratic Party. This new coalition was sworn in on 5 September 2019.

Our aim is to explain the variation in Italian foreign policy with respect to Brexit from Renzi to the first Conte government. The article is structured as follows. The next section will lay out the theoretical foundations of our argument by drawing on a neoclassical realist approach. We will then delve into the empirical observation of two issue-areas, which are particularly affected by Brexit - i.e., the Italian reaction to the Franco-German alignment and the changes in Italy's defence policy within the European context. The final section contains our conclusions.

\section{Explaining foreign policy change: a neoclassical realist argument}

In historical perspective, one may compare the current Italian foreign policy adjustment resulting from Brexit with the adaptation that followed the end of the Cold war. In that case, Italy displayed substantial continuity, as it kept Atlanticism and Europeanism as the main drivers of its foreign policy. However, the end of the Soviet threat and the wide array of security threats stemming from the Balkans led Italy to pursue a more active foreign policy (Andreatta 2001; (Walston 2007). The most immediate effect of Italy's strategic adaptation to the postbipolar scenario was its willingness to participate in multilateral peace support operations and take initiatives on its own (Tercovich 2016; Carati and Locatelli 2017).

Domestically, the end of bipolarism coincided with the end of the so-called 'First Republic', which marked the end of coalition governments led by the Christian Democratic Party. The 'Second Republic' 1 witnessed the succession of centre-left and centre-right coalition governments. The pillars of Atlanticism and Europeanism remained relevant for Italian foreign policy as both centre-left and centre-right parties strove to keep Italy firmly anchored to NATO and the EU (Alcaro 2010). In fact, a consensus emerged between centre-left and centre-right coalitions that a balance between Europeanism and Atlanticism should remain (Croci 2008). Italy's tendency to 'bandwagon' with the hegemonic power began to interact with Italy's aspiration to achieve greater regional autonomy (Ratti 2012). However, the pro-European and pro-American approaches have at times proved mutually excluding options, forcing the country 
to favour one at the expense of the other. Cladi and Webber (2011), among others (see also Brighi 2013), have tried to make sense of this balance between continuity and discontinuity by arguing that neoclassical realism provides the answer: variation between Europeanism and Americanism can be traced back to the colour of the ruling coalition - with centre-right governments willing to side with the US, and centre-left governments being pro-European.

The impact of Brexit presents striking similarities with the end of bipolarism: as long as Brexit implies a shift in the European balance of power, it equates to an external stimulus. Admittedly, the magnitude of change brought about by Brexit is not comparable to the one that followed the demise of the Soviet Union - the former being limited to the regional European sub-system, the latter having global repercussions. Moreover, while the end of bipolarism altered the hierarchy of power, Brexit cannot turn the European 'balanced multipolarity' into an 'unbalanced multipolarity', to borrow Hyde-Price's (2007) terminology. However, the effects of Brexit should not be underestimated: in fact, even if it falls short of altering the balance of power in Europe, it affects critical 'relationships' (Snyder 1996), as alignments and the patterns of conflicting and common interests. In other words, Brexit alters the situational context of the European states, forcing them to adjust accordingly.

So, how does this altered situational context look like? And how does it bother Italy? Although the effects of Brexit are still unknown, it is no mystery that France and Germany have renewed their relationship. The absence of the UK in the EU means that Italy would be left without an important partner to support endeavours to counter-balance the Franco-German tandem (Druol 2017). For a country such as Italy, it is important to consider the 'altered actor constellation and preference configuration around the Brussels table', to quote Ulrich Krotz and Joachim Schield (2018, p. 2). In fact, changes in the balance of power in Europe leads a country such as Italy to make choices in terms of adapting to it. To put it bluntly, Italy cannot risk losing the chance to continue leveraging multilateral institutions to pursue its foreign policy goals. Therefore, for Italy the main constraint caused by Brexit has been a marginalization of its voice vis-à-vis the Franco-German tandem. Following this logic, we should expect Italy to react to Brexit by increasing its activism within EU institutions and renewing its commitment to them.

However, the strategic adjustment following Brexit is not mechanistically determined: as Kenneth Waltz (1979) has argued, systemic pressures 'shape and shove' state behaviour, since they punish those actors that fail to adapt and reward those that follow suit. This is even more 
so in a low clarity, permissive strategic environment (Ripsman, Lobell and Taliaferro 2016: 4656) as the post-Brexit EU context. Consequently, Brexit results in a loose constraint, one that leaves Italy (and other EU states, for that matter) free enough to choose among different strategies in its bid to adjust its foreign policy. For these reasons, neoclassical realism is the theoretical framework that holds more potential for explanation of the Italian reaction to Brexit.

In fact, by adding a list of intervening variables at the domestic level, neoclassical realism allows us to understand how systemic stimuli are translated into foreign policy behaviour. Following the most systematic neoclassical model developed by Ripsman, Lobell and Taliaferro (2016, pp. 58-79), the intervening variables can be grouped into four first- and second-level groups: leader images, strategic culture, state-society relations and domestic institutions. In turn, combined together, these variables affect the process that leads to different policy responses, which is composed of three steps: perception, decision making and policy implementation (the so-called 'transmission belt', as Rose (1998, p. 158) put it). The model developed by Ripsman, Lobell and Taliaferro deserves credit in at least two respects. Firstly, it made an attempt to respond to the critique of ad-hocness (Legro and Moravcsik 1999; Narizny 2017). Secondly, it devised the so-called "Type III" neoclassical realism (Ripsman, Lobell and Taliaferro, 2016 pp. 80ff.) - i.e. a theoretical model that does not aim at explaining just foreign policy, but also international outcomes.

Since our purpose is more limited - i.e. explaining a single case study of foreign policy adjustment - we will stick with Type II neoclassical realism. Furthermore, compared to Ripsman, Lobell and Taliaferro, our selection of intervening variables will be narrower. As we will see in the next paragraph, in the time-frame of our analysis we will see variation in the Italian foreign policy adjustment, while at least two categories of intervening variables strategic culture and domestic institutions - remained constant. For this reason, we can leave those variables out of our model. We acknowledge, as Coticchia (2013) and Rosa $(2014 ; 2018)$ have shown amongst others, that strategic culture contributes to shaping Italian foreign policy. However, we believe that the impact of strategic culture is limited to a pro-EU and war-averse orientation. Subsequently, it can account for Rome's activism and commitment to the EU, but not for a variation in terms of Rome's approach to the Franco-German tandem. Likewise, domestic institutions have not changed since 2016, so this variable cannot have explanatory power. Finally, leader images have also a limited impact: the three prime ministers who have been in power since 2016 certainly had different mindsets and policy styles, but this mainly 
affected their rhetoric and not their substance. The main example here is the transition from Matteo Renzi to Paolo Gentiloni, both belonging to the same party.

We are therefore left with a set of variables, broadly referred to as state-society relations - in other words, how the foreign policy executive mediates with social actors such as electoral constituencies or interests groups. Following Pohl et al. (2016), we refer to this variable as governmental interest. The latter is a type of variable that matters the most in the short term, as suggested by Ripsman, Lobell and Taliaferro (2016) (and this is most true in a political context like Italy, where governments generally last for less than two years). In fact, governmental leaders must demonstrate coherence with their electoral manifesto and competence in their institutional role. In so doing, they take foreign policy actions aimed at pleasing both their constituencies and relevant interests groups.

For our purposes, governmental interest holds more explanatory power than other intervening variables due to the significant variations in government since 2016: the cabinets led by Renzi, Gentiloni and Conte had very different political platforms, stemming in turn from different coalitions. Governmental interest also allows us to focus on one key domestic process decision making - leaving aside perception and policy implementation. This is in line with the model developed by Ripsman, Lobell and Taliaferro (2016), who concede that the state-society relations do not affect perceptions. Contrary to this model, however, we hold that the impact of this variable on the implementation phase is negligible - a likely assumption, considering that by definition government interest shapes the decision phase of a policy, not its implementation.

So, in their response to Brexit, we argue that Italian policymakers tried to adjust Italian foreign policy in ways that maximized their chances to remain in office. This could be achieved in three ways: firstly, to bandwagon with France and Germany, forming a sort of $2+1$ relationship with them. In so doing, Italian policymakers could raise their voice and avoid being excluded by their powerful allies. The second option was to replace either Paris or Berlin and establish a new dyadic leadership with the remaining partner. The third option was plain opposition, with a view to counterbalancing the Franco-German partnership and preventing, or at least delaying, its effects.

Summing up, following a neoclassical realist model, we argue that Brexit acted as a systemic stimulus, forcing successive governments to adjust foreign policy orientation. As a result, 
Italy's commitment to the EU as well as participation in ongoing multilateral expeditionary operations result from external pressures, which act as contextual constraints. Nevertheless, we argue that the strategies implemented to compensate for the British departure from the EU can be explained in light of changing governmental interests. For instance, the concomitant rise of populist and extreme right parties led to declining levels of trust towards the EU (Olmastroni and Pellegata 2018; Mosca and Tronconi 2019; for a different take on the League see Verbeek and Zaslove 2015). We should observe, as a consequence, a major departure of the first Conte government from his predecessor Gentiloni in terms of foreign policy adjustment. In what follows, we tackle these questions with reference to the Italian attempts to join France and Germany in the shaping of a European response to Brexit and Italian defence policy in an altered context.

\section{Between France and Germany: Italy's European Foreign Policy after Brexit}

In terms of foreign policy, since 2016, three successive governmental coalitions have been faced with the common prospect of responding to the external pressure represented by Brexit and the consequent Franco-German alignment. In fact, without the UK, Italy understood that its leverage within the EU was at stake: it would lose an important ally to rely upon in its search for support vis-à-vis larger European countries such as France and Germany (Carbone et al. 2011). Moreover, Paris and Berlin took their cooperation forward, both bilaterally and in the EU (Kempin and Kunz 2017; Deschaux-Dutard 2019).

For the purpose of this article, it is useful to understand the different international orientations between the Democratic Party on one hand and the so-called populist alternatives on the other. The Democratic Party is traditionally pro-EU. Its founding father, Romano Prodi, served as President of the European Commission from 1999 to 2004. As witnessed in the 2014 European elections, when the party won a landslide victory, it was rewarded for its attempt to make Italy "a proud Europeanist [...] eager to set things straight in order to be able to make its voice heard in a united Europe" (Lucarelli 2015, 56). Renzi and Gentiloni differed in their rhetoric towards the European institutions and other EU partners, but their approach remained coherent with this orientation. On the other hand, the League and Five Stars Movement shared a harsh antiEuropean (Donadio 2019) stance. Both parties fiercely criticized the EU policies - immigration in primis - as well as the general principle of authority delegation inherent in the integration 
process. Such an orientation was coupled with a flamboyant rhetoric, aimed at portraying both parties as disrupting forces in the Italian political landscape. Such an intent was evident most clearly in the so-called 'contract of government' - a 58-pages document singling out the priorities of the yellow-green alliance. In the declarations surrounding the assignment of the first Conte government, the main claim was to bring about a 'government of change'. As the term implied, the supporting coalition found a common denominator in the opposition to previous policies, with the result of compelling the first Conte government to set a different foreign policy course.

Italy generally stuck by EU consensus during Brexit talks. Its tone has been more pragmatic towards Britain compared to other EU countries (Politi and Brunsden 2017). Italy supported Germany's call for Europe to do more by itself (Theil 2017): one evidence of Italian activism came just a few weeks ahead of the Bratislava summit, when Rome circulated two documents aimed at revamping CSDP (Documentazione per le Commissioni 2016, 28-31). Ironically, however, the Italian proposals featured many analogies with the Franco-German initiative, raising the suspect that - rather than promoting further EU cooperation - the main Italian purpose was to leave a mark and avoid being excluded by the major powers. When France and Germany took the initiative to launch PESCO, they had to settle on a controversial issue: while France called for ambitious commitment on the side of the participating states, Germany favoured a more inclusive approach (Billon-Galland and Quencez 2017, 2-3; Marrone 2017, 3 4). Eventually, at the July 2017 summit, the German perspective prevailed, and soon thereafter Italy and Spain were invited to co-sign their proposal, which was officially launched by the EU in November 2017 (Council of the EU 2017). As Sven Biscop (2018, 166) reminds us, as PESCO participants, 'If the big four were thus to gradually integrate requirements and procurement, the other EU members would have no choice but to join in'.

Therefore, a constant concern for the post-Brexit period in Italian foreign policy circles has been the fear of being sidelined by France and Germany. Italy had to adjust to this external pressure and it could do so by pursuing strategies discussed at the end of section 2 of this article. The Renzi and Gentiloni governments clearly opted for the first strategy (i.e. intruding the Franco-German tandem). One might easily find differences in style between the two leaders: for instance, Coticchia and Davidson (2019) stress Renzi's domestic focus and harsh rhetoric when dealing with the EU - a point that definitely sets him apart from his successor. However, compared to the first Conte government, they display more similarities than differences. One 
trait that stands out is the diplomatic activism displayed by both leaders. In his six months in power following the referendum on Brexit, Renzi made a tangible (although vain) effort to make Italy stand side by the side with France and Germany (Dessi and Olmastroni 2017). This is witnessed both at the EU level, with the above-mentioned September 2016 proposals to revamp CSDP, and in the form of state-to-state cooperation: in particular, Renzi hosted a summit with Merkel and Holland at the end of August 2016 on the symbolic Ventotene island ${ }^{2}$ (Camporini and Marrone 2016, 8). None of these initiatives led to direct accomplishments for Italy, but they all signaled the Italian will to avoid being left aside. On the contrary, in line with Renzi's political platform, they launched a two-fold message: towards Europe, they promoted the role of Italy as honest broker and key driver of the future integration process; towards the domestic audience, they conveyed the leadership role of the Prime Minister.

Paolo Gentiloni's reaction to the Franco-German partnership has followed a similar path (Felsen 2018). In fact, it is in line with the long-established style of Italian diplomacy, which is based on launching and hosting multilateral summits to raise the international prestige of the country (Cladi and Locatelli 2019): in his 18-months tenure, Italy hosted a number of highlevel diplomatic meetings, such as the G-7 Summit in Taormina, in May 2017. With reference to the European context, Gentiloni tried to capitalize on the ceremony held in Rome on 25 March 2017 to celebrate the $60^{\text {th }}$ anniversary of the Rome Treaties. In his account of the event, Gentiloni stresses how he conceived the meeting not just as a showcase for the country, but as an opportunity to revamp the European integration process (Gentiloni 2018, 82-89).The real sense of the Italian role with respect to France and Germany is pictured most vividly in a later passage, as he claimed that Macron and Merkel have different visions about Europe (the former supporting an overly ambitious project, while the latter even too pragmatic): 'this situation opens up an evident room [for Italy] ... Our national interest and our vision of the European project allow us to play a role that is even higher than the one we have as a third country of the Eurozone' (Gentiloni 2018, 93). In summary, Gentiloni's ambition was to be treated as a peer by Paris and Berlin, by taking advantage of the diplomatic space between its two major allies. Moreover, as Fabbrini and Zgaga $(2019,287)$ have argued, Gentiloni's own style in dealing with other European leaders, averse to head-on clashes, was seen as 'a guarantee of Italy's reliability'. Probably, the main initiative in this vein was the idea of a 'Quirinal Treaty' (whose name was chosen to resemble the Élysée Treaty) with France - an unaccomplished job, since it came too close to the elections that brought to power the League and the Five-Star Movement. 
The first Conte government did not share the same vision of the EU. Since his appointment, the Prime Minister has been particularly careful in keeping a distance from the flamboyant rhetoric of his Euro-skeptic supporters. However, Conte has expressed a critical stance towards the EU institutions as well as other Member States on more than one occasion. Such a stance naturally flows from the so-called contract of government. Among these goals, at the bottom of the list, it is clearly stated that reforming the European Union should be a clear priority of the newlyinstalled government, with a particular concern for migration policies (reform of the Dublin Regulation) and economic austerity. The discontinuity with the previous Gentiloni government was felt in crucial policy areas such as budgetary policy and migration policy (Fabbrini and Zgaga 2019).

As concerns the bilateral ties with other European states, the yellow-green government has not brought about the revolution that many feared (Marrone 2018a). However, compared to its predecessor, a change of alignments has occurred. Three in particular stand out: firstly, the growing and deepening connection with China, as made most visible by the negotiations to sign a memorandum of understandings with Beijing concerning the Italian involvement in the Belt and Road Initiative. Secondly, the trumpeted affinity with Orban's Hungary and the so-called Visegrad countries. Last, but certainly not least, the heightened tension with France, which is the issue that marks the most striking discontinuity from the previous governments.

It is worth remembering that the partnership between Rome and Paris has been difficult for a number of years. However, since the British referendum, issues such as the future of Libya, the merger between Fincantieri and Stx and migrant flows across the Mediterranean have further exposed the Franco-Italian relationship. When the first Conte government took office in June 2018, it changed its approach to France in at least two respects: first, it patently managed to portray France (and its President in particular) as a bogeyman to increase its domestic consensus; secondly, it deliberately increased tensions, as witnessed by the diplomatic crisis which led France to summon the Italian ambassador in Paris and recall its ambassador in Rome (a crisis apparently eased by the intervention of President Mattarella). This strategy may look irrational, and in the long run is likely to be reversed, but our model can help to explain it: on one side, Italy's policy towards France depended on the attempt to thwart the effects of the Franco-German tandem and on the other side, it was the result of the competition for consensus between the parties of the ruling coalition (Darnis 2019, 4). For our purposes, the European foreign policy of the first Conte government can be labeled as a strategy of opposition. 
At the time of writing, the second Conte government is supported by a new coalition. The influence of the Democratic Party could bring relations with Brussels, France and Germany 'back to normality', as Italy's former representative to NATO Stefano Stefanini said (quoted in Horowitz 2019). Conte called for a shared project, adding that Italy's isolationism would not serve Italian interests. In a speech delivered to the Italian lower house, Conte appeared willing to follow a different foreign policy course, by stating 'we want to put behind us the din of useless declarations and belligerent, bombastic statements...the language of this government will be mild-mannered' (quoted in Rettman 2019). As current events continuously shape the current government's foreign policy, it is not possible to add further considerations at this stage.

\subsection{Italy's defence policy in an altered European context}

The second set of empirical observations concerns the effects of Brexit on Italy's defence policy. No matter how the future EU-UK partnership will look, Brexit may affect the current state of European armaments cooperation (Turpin 2019). In fact, one may argue that it has already led to significant effects, for example during the Bratislava Summit in September 2016, EU and European leaders designed a number of initiatives aimed at revamping defence cooperation - the aforementioned PESCO, the European Defence Fund (EDF) and the Coordinated Annual Review on Defence (CARD). Moreover, in light of the traditional British opposition to the European Defence Agency as a catalyst for defence cooperation, it is reasonable to expect that in the future the agency would be strengthened, to the benefit of the whole European Defence Technology Industrial Base (DTIB) (Mawdsley 2015). However, on the other hand, without the UK, the EU DTIB would lose its main pillar (Schütz and Mölling 2018, 4).

Disagreement persists over the most likely shape of the future scenario (for a thorough analysis of possible alternatives, see Martill and Sus 2018, but also Calcara 2017): however, for the sake of our analysis, the question is: is Brexit pushing Italy towards more cooperation with its European counterparts? What kind of response should we expect by the light of the three options discussed in section 2? In order to answer these questions, we should observe in the first place how Italy approached the EU defence initiatives. Rome has found in PESCO and the EDF a great opportunity to enhance its capabilities, overcome tight budget constraints and 
sustain the national defence industry. Driven by these considerations, Italian policymakers have supported PESCO since its conception, and they still show remarkable appreciation of it, regardless of the changes occurred in the ruling coalition (Marrone 2018b). A closer look at the projects launched in 2018 confirms this approach: in the first set of projects, launched in March 2018, Italy took part in 15 projects out of 17, taking the lead in 4 . In the second set, announced in November, the Italian participation was limited to 6 projects out of 17, 3 of which with a leading role. ${ }^{3}$ All in all, Rome's involvement in PESCO amounts to 21 projects - a figure which makes Italy the highest contributing state equally placed with France (Marrone and Sartori 2019, 6-7).

It is worth stressing that France and Italy have assumed a leading role in this endeavour: from this perspective, Germany, participating in just 13 projects, lags far behind. The central role played by Paris and Rome is also witnessed by the sheer number of projects that involve FrenchItalian cooperation: with 12 projects, Italy and France cooperate in more than a half of the projects they participate in. Equally relevant, the German role is highly related to the relationship with Paris, since 12 out of 13 German projects see a French involvement. So, in comparison withthe political dimension discussed in the previous paragraph, two factors contribute to making the Franco-German partnership in military issues problematic: the German reluctance to commit to EU projects - at least compared with France - and the Italian (and to a lesser extent Spanish) willingness to share leadership with Paris.

Further evidence of the Italian interest for PESCO can be found by observing the kind of projects which have involved the Italian participation. In fact, the projects launched so far display very different levels of effort and ambitions: some are just the formalisation of ongoing efforts (such as the European Medical Command led by Germany), others imply expensive, multi-year, capability-oriented programs. This is the case, for instance, of the European Military Space Surveillance Awareness Network (EU-SSA-N), jointly developed by France and Italy, and the so-called Eurodrone (officially the European Medium Altitude Long Endurance Remotely Piloted Aircraft Systems - MALE RPAS), which builds on a previous program originally developed by France, Germany and Italy and subsequently with participation from Spain and Czech Republic.

Under the Gentiloni government, Italy reluctantly agreed to participate in a project unveiled by French President Macron during a speech at Sorbonne University in September 2017, namely 
the European Intervention Initiative (EII). France invited 9 countries to participate (Belgium, Denmark, Estonia, Germany, Italy, the Netherlands, Portugal, Spain and the UK) (Biscop 2018). Macron envisaged that, by the beginning of the next decade, participating states will have achieved a common intervention force, a common defence budget and a common doctrine for action (Boffey 2018). Macron conceived EII as independent of the EU - de facto based on a "coalition of the willing" principle - and as a way of overcoming the inability of the EU to rapidly respond to potential crises (Mills 2018). For a variety of reasons - rising tensions between Rome and Paris, preference for the EU and NATO frameworks, fears of an excessive French influence (Marrone 2018b, 7) - the newly-installed government decided to drop out of the initiative in June 2018. However, in September 2019, the newly-installed second Conte government announced Italy would eventually be part of the initiative.

As concerns the EDF, Italy explicitly claimed that this instrument should be conceived as complementary to PESCO (see on this point the statements by then Minister of Defence Elisabetta Trenta and Deputy Defence Minister Angelo Tofalo, cited in Marrone 2018b, notes 8-9): it follows that Italy has played a very active role in the negotiations leading up to the European Defence Industrial Development Programme (EDIDP). In particular, as noted by Marrone and Sartori $(2019,16)$, one of the priorities of the Italian government was to set as a requisite for application, that at least three partners from three different countries were part of the consortium. Once again, an attempt to avoid forms of exclusive cooperation between Berlin and Paris, and a window of opportunity to join their partnership.

Finally, although (partially) independent from the Italian Government, we can't fail to take into consideration the role of Leonardo (formerly known as Finmeccanica), Italy's first defence industry. Leonardo is fully integrated in the European defence market, mostly through a web of joint ventures with other EU companies (Caruso and Locatelli 2013) but it also sells on the British and American markets. With about 27 industrial complexes and 7000 employees working in the UK, the impact of Brexit might be severe for the company (Calcara 2017, 145). For these reasons, on one side the company has a clear interest in the EU initiatives aimed at strengthening the European DTIB, but on the other side it is not constrained by the European market. It follows that Leonardo's approach will be opportunistic, and this in turn may shape the Italian government's behaviour. 
Two cases in point are illustrative. In 2018, Leonardo won as a leading institution one of the few Preparatory Actions for Defence Research (PADR) grants within the EDF scheme. OCEAN 2020 is a €35-millions, 42-partners project aimed at developing a framework for maritime operations that integrates enhanced air, naval surface and underwater unmanned systems. On the other hand, a few month later, at the Farnborough Airshow, the British Defense Secretary Gavin Williamson unveiled the project for a sixth-generation fighter aircraft, named Tempest, manufactured by a consortium led by BAE Systems that included Leonardo. ${ }^{4}$ The problem for Italy is that in the EU context, France and Germany (later joined by Spain) are working on a different project - the Future Combat Air System (FCAS). After more than a year of hesitation, Italy eventually decided to join the British-led project.

In conclusion, the previous discussion on the Italian efforts to deepen military cooperation after Brexit leads to three considerations: firstly, just like the political dimension, the Italian approach in this realm has been characterised by sustained activism: Italy first sponsored the launch of PESCO and the EDF, and has participated in many ambitious projects. Secondly, compared to the political dimension, Italy has not seen the Franco-German partnership as a challenge: indeed, due to Berlin's lack of commitment, defence integration has so far been led mostly by Paris, so giving Rome more room to maneuver. Thirdly, the defence policy of the first Conte government displayed substantial continuity with the previous governments, which is markedly different to its strategy on foreign policy. This outcome is consistent with the neoclassical Realist model, as it reflects both the systemic pressure and the governmental interest of the governments that succeeded after Brexit: promoting and financing defence initiatives is not just a strategic response to the loss of an important partner like the UK, but is also coherent with the governmental interest of any executive - i.e. keeping powerful interest groups' consensus.

Therefore, in contrary to the foreign policy dimension, here discontinuities from Renzi to Conte are minimal. In terms of our model, our conclusion is that in terms of defence policy successive Italian governments have tried to forge a new tandem with France. Why is this the case? In particular, why did the first Conte cabinet display an oppositional foreign policy stance and a cooperative approach to defence? The answer lies in both the lower political saliency of defence policy compared to foreign policy and the coalition dynamics of the Conte government: broadly speaking, while the Five-Stars Movement had a clear pacifist platform (cutting the defence budget, dropping the F-35 program, reviewing Italy's involvement in peace operations, etc.), the League had a markedly conservative stance (providing the Armed Forces with the necessary 
funding, protecting the national defence industrial base, etc.). As a result, the final agreement undersigned in the contract of government (Contratto per il governo del cambiamento 2018, 17) resulted in a least common denominator (a mere 16 lines), with most of the contentious issues left untouched. Clerly, the bargaining process saw the League gaining the upper hand, as none of the points raised by the Five-Stars Movement was listed in the "contract". Finally, as defence issues are mostly excluded from public debate, the first Conte government sought the consensus of interest groups rather than of public opinion.

\section{Conclusions}

This article aimed to illustrate the consequences of Brexit on Italian foreign and defence policy and account for the variations from the Renzi government to the first Conte government. As we have seen, after the Brexit referendum Italy has sought to adjust to a shifting balance of power within the EU. In fact, whilst Brexit did not alter the overall balance of power in Europe, it altered alignments among the European powers. The example of the increased pattern of cooperation between France and Germany illustrates this. The consequences for Italy were that it had to rethink its foreign policy because it could not count on British support to counterbalance the Franco-German partnership any longer. For this reason, at least indirectly, Brexit has had an effect on Rome's foreign policy.

In order to deal with the Franco-German alignment, Italy has followed different strategies: under the leadership of Renzi and Gentiloni it has tried to break in the partnership and forge a sort of triumvirate with France and Germany. On the contrary, the first Conte government has taken a confrontational stance against France, with a view (among other things) to delaying its influence in Europe. So, the Italian reaction to Brexit has been marked by continuity as well as change. In terms of defence policy, instead, Brexit has pushed Italy to cooperate more in an EU-framework, with no concern for the Franco-German tandem.

In order to make sense of this variation, we have resorted to a neoclassical Realist framework: coherently with this approach, we have considered the external constraints posed by Brexit as the independent variable, whose effect has been mediated by domestic-level intervening variables. In our single case-study research design, we have had the possibility to keep a number of variables such as executive autonomy, governmental instability and interest groups constant: 
as a result, we have focused exclusively on governmental interests, which we defined as the need to display competence and coherence with the electoral manifesto. In a nutshell, with reference to foreign policy, the observed variation between the Renzi and Gentiloni governments on one side, and the first Conte government on the other, is the result of different definitions of governmental interest: while the former tried to show competence mostly with reference to the international audience, the latter was focused almost exclusively on the domestic arena; likewise, since the yellow-green government coalition based its manifesto on change from the past, it took pride in trumpeting a new course in Italian foreign policy. On the other hand, as concerns defence policy, the political platform of all ruling coalitions displayed significant elements of continuity, so explaining why the first Conte government acted in substantial continuity with the past. 


\section{References}

Alber, Elisabeth. 2019. "How Brexit affects Italy - and its Eurosceptic politicians". LSE Blog. https://blogs.lse.ac.uk/europpblog/2019/02/21/how-brexit-affects-italy-and-its-euroscepticpoliticians/.

Alcaro, Riccardo. 2010. "Catching the change of tide. Italy's post-Cold War security policy.", The International Spectator 45 (1): 131-145. doi: https://doi.org/10.1080/03932720903562601. Andreatta, Filippo. 2001. "Italy at a Crossroads: The Foreign Policy of a Medium Power after the end of Bipolarity.", Daedalus 130 (2), 45-65.

Billon-Galland, Alice, and Martin Quencez. 2017. "Can France and Germany make PESCO work as a process toward EU defence?", Washington, DC: German Marshall Fund of the United States, Policy Brief No. 33, October 6. https://www.europeanleadershipnetwork.org/policybrief/can-france-and-germany-make-pesco-work-as-a-process-toward-eu-defence/.

Biscop, Sven. 2018. "European Defence: Give PESCO a Chance.”, Survival, 60 (3), 161-180. doi: https://doi.org/10.1080/00396338.2018.1470771.

Boffey, Daniel. 2018. "Nine EU states sign off on joint military intervention force." The Guardian, June 25.

Brighi, Elisabetta. 2011. "Resisting Europe? The Case of Italy's foreign policy”, in National and European Foreign Policies: towards Europeanisation, edited by Christopher Hill and Reuben Wong, 55-71. London: Routledge.

Brighi, Elisabetta. 2013. Foreign Policy, Domestic Politics and International Relations. The case of Italy. London: Routledge.

Calcara, Antonio. 2017. "Brexit: what impact on armaments cooperation?”, Global Affairs, 3 (2), 139-152. doi: https://doi.org/10.1080/23340460.2017.1342555.

Camporini, Vincenzo, and Alessandro Marrone. 2016. "Recent Developments in Italy's Security and Defence Policy", Documenti IAI, No. 19, November 19. https://www.iai.it/sites/default/files/iai1619.pdf.

Carati, Andrea and Andrea Locatelli. 2015. “Ticket to Ride: Italy's Participation to Multilateral Missions and the Preservation of its International Status", paper presented at the annual BISA Conference, London (UK), June 17.

Carati, Andrea and Andrea Locatelli. 2017. “Cui prodest? Italy's questionable involvement in multilateral military operations amid ethical concerns and national interest", International Peacekeeping, 24 (1), 86-107. doi:https://doi.org/10.1080/13533312.2016.1229127. 
Carbone, Maurizio, Valter Coralluzzo, Raffaella Del Sarto, and Nathalie Tocci. 2011. "Italy in the Mediterranean: between Atlanticism and Europeanism". In: Italy in the post-Cold War order: adaptation, bipartisanship, visibility, edited by Maurizio Carbone, 197-214. New York: Lexington Books.

Caruso, Raul, and Andrea Locatelli. 2013. “Company Survey Series II: Finmeccanica amid International Market and State Control. A Survey of Italian Military Industry", Defence and Peace Economics 24 (1): 89-104. doi: https://doi.org/10.1080/10242694.2011.635952.

Cladi, Lorenzo, and Mark Webber. 2011. "Italian foreign policy in the post-Cold War period: a neo-classical realist approach.”, European Security 20 (2): 205-219. doi: https://doi.org/10.1080/09662839.2011.565052.

Cladi, Lorenzo, and Andrea Locatelli. 2019. "Why did Italy contribute to UNIFIL II? An analytical eclectic analysis.", Italian Political Science Review/Rivista Italiana di Scienza Politica, 49 (1): 85-97. doi: https://doi.org/10.1017/ipo.2018.10.

Coticchia, Fabrizio. 2013. Qualcosa è cambiato? L'evoluzione della politica di difesa italiana dall'Iraq alla Libia (1991-2011). Pisa: Pisa University Press.

Coticchia, Fabrizio, and Jason Davidson. 2019. Italian Foreign Policy during Matteo Renzi's Government: A Domestically Focused Outsider and the World. Lanham (MD): Lexington Books.

Contratto per il governo del cambiamento 2018, http://download.repubblica.it/pdf/2018/politica/contratto_governo.pdf.

Council of the European Union. 2017. "Defence cooperation: 23 member states sign joint notification on the Permanent Structured Cooperation (PESCO)." November 13. https://www.consilium.europa.eu/en/press/press-releases/2017/11/13/defence-cooperation-23member-states-sign-joint-notification-on-pesco/pdf.

Croci, Osvaldo. 2008. "Not a Zero-Sum Game: Atlanticism and Europeanism in Italian Foreign Policy." The International Spectator, $43 \quad$ (4): 137-155. https://doi.org/10.1080/03932720802486498.

Darnis, Jean-Pierre. 2019. "The Political Rollercoaster of Italian-French Relations." IAI Commentaries, No. 14, February 20. https://www.iai.it/sites/default/files/iaicom1914.pdf. Deschaux-Dutard, Delphine. 2019. "The French-German Military Cooperation and the Revival of European Defence After Brexit: Between Reality and Political Myth.” In Peace, Security and Defence Cooperation in Post-Brexit Europe. Risks and Opportunities, edited by: CorneliaAdriana-Baciu and John Doyle, 53-78. Cham: Springer Nature Switzerland. 
Dessi, Andrea, and Francesco Olmastroni. 2017. "Foreign Posture in Comparative Perspective: A Quantitative and Qualitative Appraisal of Italian Foreign and Defence Policy during the Renzi Government." Contemporary Italian Politics, 9 (2): 201-218. https://doi.org/10.1080/23248823.2017.1338447

Donadio, R. (2019) The New Populist Playbook, The Atlantic, available at https://www.theatlantic.com/international/archive/2019/09/matteo-salvini-italy-populistplaybook/597298/

Documentazione per le Commissioni. 2016. "Riunione della Commissione Affari esteri del Parlamento europeo (AFET)", Senato della Repubblica, Servizio Studi Europei N. 39, Camera dei Deputati, Ufficio Rappporti con l'Unione Europea N. 72, November 8. https://www.senato.it/service/PDF/PDFServer/BGT/00993772.pdf.

Druol, E.M. (2017) 'Rethinking Franco-German relations: a historical perspective', available at https://bruegel.org/wp-content/uploads/2017/11/PC-29-2017.pdf, visited on 21 January 2020.

Duke, Simon. 2019. Will Brexit damage our security and defence?. New York: Palgrave Macmillan.

Fabbrini, Sergio, and Tiziano Zgaga. 2019. "Italy and the European Union: the discontinuity of the Conte government." Contemporary Italian Politics 11 (3):280-293. doi: https://doi.org/10.1080/23248823.2019.1642657.

Felsen, David. 2018. "Italian foreign policy under the Gentiloni government: do the "three circles' hold in 2017?" Contemporary Italian Politics 10 (4): 363-376. doi: https://doi.org/10.1080/23248823.2018.1544352.

Gentiloni, Paolo. 2018. La sfida impopulista. Da dove partire per tornare a vincere. Milan: Rizzoli.

Giacomello, Giampiero and Bertjan, Verbeek. eds. 2011. Italy's foreign policy in the twentyfirst century: the new assertiveness of an aspiring middle power. Lanham: Rowman.

Hyde-Price, Adrian. 2007. European Security in the 21st Century: The Challenge of Multipolarity. Abingdon, UK: Routledge.

Horowitz, Jason. 2019. "New Government takes shape in Italy, sidelining Salvini and the Hard Right." The New York Times, August 28.

Kempin, Ronja, and Barbara Kunz. 2017. "France, Germany and the Quest for European Strategic Autonomy: Franco-German Defence Cooperation in A New Era.” Berlin: German Institute for International and Security Affairs. December 
https://www.ifri.org/sites/default/files/atoms/files/ndc_141_kempin_kunz_france_germany_e uropean_strategic autonomy_dec 2017.pdf.

Kirchgaessner, Stephanie. 2016. "Italian PM Matteo Renzi resigns after referendum defeat." The Guardian, December 5.

Krotz, Ulrich and Joachim Schield. 2018. "Back to the future? Franco-German bilateralism in Europe's post-Brexit union.” Journal of European Public Policy 25 (8):1174-1793. doi: https://doi.org/10.1080/13501763.2018.1467951.

Legro, Jeffrey W., and Andrew Moravcsik. 1999. “Is Anybody Still a Realist?”, International Security 24 (2), 5-55. https://doi.org/10.1162/016228899560130.

Lucarelli, Sonia. 2015. "Italy and the EU: From True Love to Disenchantment?" Journal of Common Market Studies 53 (1): 40-60. doi: https://doi.org/10.1111/jcms. 12274.

Marrone, Alessandro. 2018a. "The Conte Government: Radical Change or Pragmatic Continuity in Italian Foreign and Defence Policy?", IAI Commentaries, No. 33, June 15, https://www.iai.it/sites/default/files/iaicom1833.pdf.

Marrone, Alessandro. 2018b. "PeSCo. The Italian Perspective", Ares Policy Paper No. 30, September 20, http://www.iris-france.org/wp-content/uploads/2018/09/Ares-30.pdf.

Marrone, Alessandro. 2017. "Permanent Structured Cooperation: An Institutional Pathway for European Defence", IAI Commentaries, No. 26, November 20, https://www.iai.it/en/pubblicazioni/permanent-structured-cooperation-institutional-pathwayeuropean-defence.

Marrone, Alessandro,. and Paola Sartori. 2019. "Recenti sviluppi verso la difesa europea: opportunità e sfide per l'Italia”, Osservatorio di Politica Internazionale N. 148, January, https://www.iai.it/sites/default/files/pi a 0148.pdf.

Martill, Benjamin, and Monika Sus. 2018., "Post-Brexit EU/UK security cooperation: NATO, CSDP+, or 'French connection'?" The British Journal of Politics and International Relations 20 (4): 846-863. https://doi.org/10.1177/1369148118796979.

Mawdsley, Jocelyn. 2015. "France, the UK and the EDA". In: The European Defence Agency. Arming Europe, edited by Nikolaos Karampekios, and Iraklis Oikonomou, 139-154. London: Routledge.

Mills, Claire. 2018. "The European Intervention Initiative (EII/EI2)”, House of Commons Library, Briefing paper no. 8432, http://researchbriefings.files.parliament.uk/documents/CBP8432/CBP-8432.pdf. 
Mosca, Lorenzo and Filippo Tronconi. 2019. "Beyond Left and Right: The Eclectic Populism of the Five Star Movement." West European Politics 42 (6): 1258-1283. https://doi.org/10.1080/01402382.2019.1596691.

Narizny, Kevin. 2017. "On Systemic Paradigms and Domestic Politics: A Critique of the Newest Realism”, International Security $42 \quad$ (2): 155-190. https://doi.org/10.1162/ISEC_a_00296.

Nissen, Christine. 2017. Forged in Crisis: the EU's Common Security and Defence Policy after Brexit, Copenhagen: Danish Institute for International Studies.

Olmastroni, Francesco. and Alessandro Pellegata. 2018. "Members apart: a mass-elite comparison of mutual perceptions and support for the European Union in Germany and Italy." Contemporary Italian Politics 10 (1). 56-75. https://doi.org/10.1080/23248823.2018.1436620. Pohl, Benjamin, Niels van Willigen, and Cynthia van Vonno. 2016. "Governmental interest, new Liberalism and the CSDP". In International Relations Theory and European Security: We Thought We Knew, edited by Lorenzo Cladi and Andrea Locatelli, 65-83, Abingdon: Routledge.

Politi, James, and Jim Brunsden. 2017. “Italy’s Paolo Gentiloni calls for 'tailor-made' UK-EU deal." Financial Times, December 13.

Ratti, Luca. 2012. “All Aboard the Bandwagon? Structural Realism and Italy's International Role.” Diplomacy and Statecraft $23 \quad$ (2). 87-109. https://doi.org/10.1080/09592296.2012.651964.

Rettman, Andrew. 2019. 'Italy's PM Conte: no more anti-EU populism.' EU Observer, September 10, https://euobserver.com/political/145885.

Ripsman, Norris M., Lobell, Steven E. and Taliaferro, Jeffrey W. 2016. Neoclassical Realist Theory of International Politics, Oxford: Oxford University Press.

Rosa, Paolo. 2014. “The accommodationist state: Strategic culture and Italy's military behavior." International Relations 28 (1). 88-115. DOI: https://doi.org/ $10.1177 / 0047117813486821$.

Rosa, Paolo. 2018. "Patterns of strategic culture and the Italian case." International Politics 55 (2). 316-333. DOI: https://doi.org/10.1057/s41311-017-0077-1.

Rose, Gideon. 1998. "Neoclassical Realism and Theories of Foreign Policy." World Politics 51 (1). 144-172. DOI: https://doi.org/10.1017/S0043887100007814.

Schütz, Torben, and Christian Mölling. 2018. "Fostering a Defence-Industrial Base for Europe: The Impact of Brexit, IISS-DGAP, June, https://www.iiss.org/- 
$\underline{\text { media/images/comment/military-balance-blog/2018/june/fostering-a-defence-industrial-base- }}$ for-europe-iiss-dgap.ashx.

Snyder, Glenn H. 1996. "Process variables in neorealist theory” In Security Studies, 5 (3), $167-$ 192. https://doi.org/10.1080/09636419608429279.

Theil, Stefan. 2017. “Berlin's Balancing Act.” Foreign Affairs 96. 9-16.

Tercovich, Giulia. 2016. "Italy and UN Peacekeeping: Constant Transformation." International Peacekeeping 23 (5). 681-701. http://dx.doi.org/10.1080/13533312.2016.1235094.

Turpin, Lee D. 2019. "UK-EU Military Cooperation and Brexit from a Neoclassical Realist Perspective: No Big Deal?" In Peace, Security and Defence Cooperation in Post-Brexit Europe. Risks and Opportunities, edited by Cornelia-Adriana-Baciu, and John Doyle, 3-28. Cham: Springer Nature Switzerland.

Veerbek, Bertjan, and Andrej Zaslove. 2015. "The Impact of Populist Radical Right Parties on Foreign Policy: The Northern League as a Junior Coalition Partner in the Berlusconi Governments." European Political Science Review 7 (4), 525-546. https://doi.org/10.1017/S1755773914000319.

Walston, James. 2007. 'Italian foreign policy in the 'Second Republic'? Changes of Form and Substance.” Modern Italy 12 (1). 91-104. https://doi.org/10.1080/13532940601134916.

Walston, James. 2011. "Italian Foreign Policy since the end of the Cold War". In Italy in the Post-Cold War Order. Adaptation, Bipartisanship, Visibility edited by Maurizio Carbone, 6579, Lanham MD: Rowman.

Waltz, Kenneth N. .1979. Theory of International Politics. New York: McGraw Hill.

\footnotetext{
${ }^{1}$ The Second Republic began in 1994 following a series of events, which led to a comprehensive investigation called Mani Pulite (Italian for 'Clean Hands').

${ }^{2}$ In 1941, while jailed in Ventotene, Altiero Spinelli and Ernesto Rossi wrote their famous document Per un'Europa libera e unita, broadly known as the Ventotene Manifesto.

${ }^{3}$ This figure may lead to believe that Italy's contribution to PESCO projects has shrunk from March to November, but this inference would be flawed. In fact, the second batch of projects is made mostly by bilateral and trilateral agreements. As an evidence of this, while the first batch saw an average participation of 7.5 states, this value in the second batch dropped to a mere 3.7. Data is available at https://www.consilium.europa.eu/media/37315/tablepesco-projects-updated.pdf.

${ }^{4} \mathrm{We}$ are grateful to Pietro Batacchi for bringing this point to our attention.
} 